\title{
PENINGKATAN KETERAMPILAN MENULIS GERPEN DENGAN METODE MENGILUSTRASIKAN BUKAN MEMBERITAHUKAN DAN MEDIA FILM PENDEK BERBASIS PENDIDIKAN KARAKTER PADA SISWA KELAS X IPA 2 MA MIFTAHUL ULUM WEDING BONANG KABUPATEN DEMAK
}

\author{
ZUN AUNAYA', EVI CHAMALAH ${ }^{2}$, MEILAN ARSANTI', \\ Prodi PBSI, FKIP, Universitas Islam Sultan Agung \\ zunaunaya@gmail.com', chamalah@unissula.ac.id², meilanarsanti@unissula.ac.id ${ }^{3}$
}

Pertama Diterima: 05 Agustus 2017 Bukti Akhir Diterima: 05 Oktober 2017

\begin{abstract}
Abstrak
Tujuan penelitian ini adalah (1) mendeskripsikan pelaksanaan pembelajaran menulis cerpen dengan Metode Mengilustrasikan Bukan Memberitahukan dengan media film pendek berbasis pendidikan karakter pada siswa kelas X IPA 2 MA Miftahul Ulum Weding Bonang Kabupaten Demak, (2) mendeskripsikan peningkatan keterampilan menulis cerpen denganMetode Mengilustrasikan Bukan Memberitahukan dan media film pendek berbasis pendidikan karakterpada siswa kelas X IPA 2 MA Miftahul Ulum Weding Bonang Kabupaten Demak, dan (3) perubahan sikap dan perilaku siswa kelas X IPA 2 MA Miftahul Ulum Weding Bonang Kabupaten Demak setelah mendapat pembelajaran menulis cerpen dengan menggunakan Metode Mengilustrasikan Bukan Memberitahukan dan media film pendek berbasis pendidikan karakter. Penelitian ini merupakan penelitian deskriptif kualitatif dan kuantitatif. Penelitian kualitatif berupa analisis data yang diperoleh dari pengamatan dan wawancara. Semua data yang diambil digunakan untuk menganalisis data kualitatif melalui data nontes. Penelitian kuantitatif berupa analisis nilai secara keseluruhan, dan merekap nilai tes menulis cerpen dengan Metode Mengilustrasikan Bukan Memberitahukan dan media film pendek berbasis pendidikan karakter pada siklus I, siklus II, dan siklus III, kemudian menghitung nilai rata-rata yang diperoleh. Hasil penelitian menunjukkan: (1) aspek kesesuaian isi dengan tema film pendek memperoleh rata-rata sebesar 76,25 yang semula 66,11. Aspek kesesuaian alur atau plot memperoleh rata-rata sebesar 77,58 yang semula 65,11. Aspek penggambaran tokoh dan penokohan memperoleh rata-rata sebesar 76,19 yang semula 67,69. Aspek pendeskripsian latar memperoleh rata-rata sebesar 75,63 yang semula 69,22. Aspek penggunaan gaya bahasa memperoleh rata-rata sebesar 72,86 yang semula 66,00 . (2) perubahan perilaku siswa yang semula memperoleh rata-rata 66,83 menjadi 75,70.

Kata kunci: Menulis Cerpen, Media Film Pendek, Metode Mengilustrasikan Bukan Memberitahukan, Pendidikan Karakter.
\end{abstract}

\begin{abstract}
The purpose of this study are (1) to describe the implementation of short story writing lesson with Show Not Tell Method with short film based on character education in XA IPA 2 MA Miftahul Ulum Weding Bonang, Demak, (2) to describe the improvement of short story writing skills with Show Show Method Tell and short film media based on character education in grade X students IPA 2 MA Miftahul Ulum Weding Bonang Demak District, and (3) attitude and behavior change of students of class X IPA 2 MA Miftahul Ulum Weding Bonang Kabupaten Demak after got learning to write short story by using Method Show Not Tell and short film-based educational media characters. This research is descriptive qualitative and quantitative research. Qualitative research in the form
\end{abstract}


of data analysis obtained from observation and interview. All the data taken is used to analyze the qualitative data through non-complaint data. Quantitative research in the form of value analysis as a whole, and recap the value of short story writing test with Show Not Tell Method and short film media based on character education in cycle I, cycle II, and cycle III, then calculate the average value obtained. The results showed: (1) conformity aspect of content with short film theme obtained an average of 76.25 which was originally 66,11. The plot suitability aspect obtained an average of 77.58 which was originally 65.11. Aspects of figure depiction and characterizations obtained an average of 76.19 which was originally 67.69. The background aspect aspect obtained an average of 75.63 which was originally 69.22. Aspects of the use of language style obtained an average of 72.86 which was originally 66.00. (2) changes in student behavior which originally earned an average of 66.83 to 75.70 .

Keywords: Short Story Writing, Short Film Media, Show Not Tell Method, Character Education.

\section{PENDAHULUAN}

Bahasa dan sastra Indonesia merupakan salah satu mata pelajaran yang penting diajarkan di sekolah. Peran penting yang dimiliki oleh bahasa Indonesia disebabkan oleh kedudukan bahasa Indonesia sebagai bahasa nasional bangsa Indonesia. Pembelajaran bahasa dan sastra Indonesia memiliki peran penting dalam pembentukan kebiasaan, sikap dan kemampuan dasar yang diperlukan oleh siswa untuk pertumbuhan yang dialami selanjutnya. Selain itu, pembelajaran bahasa dan sastra Indonesia juga dapat meningkatkan kemampuan berbahasa dan bersastra anak yang dapat digunakan untuk menyerap berbagai nilai serta pengetahuan yang dipelajari.

Pembelajaran bahasa dan sastra Indonesia memiliki tujuan agar peserta didik memiliki kemampuan (1) berkomunikasi secara efektif dan efisien sesuai etika yang berlaku, baik secara lisan maupun tulis; (2) menghargai dan bangga menggunakan bahasa Indonesia sebagai bahasa persatuan dan bahasa negara; (3) memahami bahasa Indonesia dengan menggunakannya dengan tepat dan kreatif untuk berbagai tujuan; (4) menggunakan bahasa Indonesia untuk meningkatkan kemampuan intelektual, serta pembelajaran sastra untuk meningkatkan kematangan emosional dan sosial anak; (5) menikmati dan memanfaatkan karya sastra untuk memperluas wawasan, memperhalus budi pekerti serta meningkatkan pengetahuan dan kemampuan berbahasa; dan (6) menghargai dan membanggakan sastra Indonesia sebagai khasanah budaya dan intelektual manusia Indonesia (Depdiknas, 2004).

Hal ini yang membuat pemerintah mencantumkan pembelajaran bahasa dan juga pembelajaran sastra ke dalam kurikulum sekolah. Dalam kurikulum pembelajaran bahasa dan sastra Indonesia diaplikasikan secara bersama, meskipun antara pembelajaran bahasa dan sastra Indonesia memiliki kompetensi-kompetensi dasar yang dibedakan. Kenyataan di 
lapangan bahwa pembelajaran sastra kurang mendapat perhatian guru untuk diajarkan di sekolah. Guru lebih cenderung mengajarkan pembelajaran bahasa dan melewati pembelajaran sastra yang seharusnya juga diajarkan secara bersama. Oleh karena itu, peneliti mencoba mengadakan penelitian dalam kaitan dengan pembelajaran sastra agar pembelajaran sastra di sekolah menjadi lebih menarik perhatian siswa sehingga siswa termotivasi untuk belajar sastra.

Ada empat komponen pembelajaran sastra yang juga ada dalam pembelajaran bahasa. Tiap komponen ini saling memengaruhi dan saling berhubungan. Keempat komponen tersebut adalah menyimak (listening skill), berbicara (speaking skill), membaca (reading skill) dan menulis (writing skill). Dari keempat komponen tersebut, keterampilan menulis dipilih dalam penelitian ini karena keterampilan ini memiliki tingkatan yang lebih tinggi dari keterampilan yang lain. Jika seseorang ingin memiliki kemampuan menulis, maka ia harus menguasai komponen lain, seperti menyimak, berbicara, dan membaca. Oleh karena itu keterampilan menulis memiliki tingkat kesulitan yang lebih dibanding dengan keterampilan yang lain (Suharianto, 2009, hal 3-7).

Menulis merupakan salah satu keterampilan berbahasa yang dipergunakan dalam komunikasi secara langsung maupun tidak langsung. Keterampilan menulis tidak didapat secara alami, tetapi harus melalui proses belajar dan berlatih. Keterampilan menulis yang baik diperoleh dengan latihan berulang-ulang dan memerlukan waktu yang tidak sebentar. Menulis merupakan salah satu kegiatan yang harus dihadapi siswa dalam proses pembelajaran, khususnya pembelajaran bahasa dan sastra Indonesia. Melalui kegiatan menulis diharapkan siswa mampu menuangkan gagasan serta ide-ide mereka dengan baik. Oleh karena itu, diperlukan pengajaran keterampilan menulis yang menggunakan teknik, metode, dan media pembelajaran yang inovatif sehingga potensi dan kreativitas siswa terhadap keterampilan menulis dapat disalurkan.

Menulis bukan pekerjaan yang sukar, melainkan juga bukan termasuk pekerjaan yang mudah. Untuk memulai menulis orang tidak perlu menunggu menjadi seorang penulis yang terampil. Teori menulis mudah untuk dipelajari, tetapi untuk mempraktikkannya tidak cukup hanya sekali dua kali.

Selain itu, keterampilan menulis mempunyai peran penting dalam menunjang daya pikir anak. Akan tetapi, banyak faktor yang menjadi penghambat bagi perkembangan keterampilan menulis. Faktor pertama berasal dari diri anak, meliputi tingkat sosial ekonomi, kebiasaan, motivasi, dan tingkat berpikir. Anak mengalami kesulitan dalam keterampilan menulis, terutama saat mengembangkan ide pikiran kedalam sebuah tulisan, serta kesulitan 
dalam merangkai kalimat dalam sebuah tulisan. Hal ini karena anak tidak terbiasa untuk mencurahkan isi hati kedalam sebuah tulisan.

Faktor kedua berasal dari luar seperti lingkungan sekolah yang berkaitan dengan sarana dan prasarana serta kondisi sekolah. Sarana dan prasarana sekolah yang kurang mendukung siswa untuk mengembangkan kompetensi siswa dalam mencurahkan gagasannya, juga memengaruhi keterampilan menulis siswa. Sarana dan prasarana ini berkaitan dengan media yang digunakan oleh guru dalam mengajar kompetensi menulis.

Faktor ketiga adalah guru yang berkaitan dengan kemampuan guru. Kompetensi guru merupakan salah satu faktor penting meningkatkan kemampuan seorang anak untuk menulis. Guru merupakan motivator sekaligus motor penggerak seorang anak untuk bisa menulis. Di sini kemampuan guru dalam hal mengajarkan menulis sangat dibutuhkan. Meskipun saat ini guru hanya sebagai fasilisator, tetapi peranan guru untuk membimbing siswa mahir menulis dibutuhkan karena seorang siswa tidak akan mahir menulis tanpa adanya sebuah bimbingan dari seorang guru.

Menulis dibedakan menjadi beberapa jenis, salah satunya adalah menulis kreatif. Menulis kreatif dapat diartikan sebagai kemampuan untuk mengendalikan pikiran-pikiran kreatif yang bergumul pada pikiran seseorang dan menyusunnya dalam sebuah kalimat dengan struktur yang baik. Menulis kreatif lebih berbobot daripada menyimpan imajinasi karena tidak semua imajinasi adalah pikiran yang kreatif. Untuk dapat menuangkan imajinasi tersebut dapat dituangkan dalam bentuk tulisan, misalnya dibuat ke dalam bentuk cerpen, puisi atau drama (Laksana 2007, hal 3).

Dalam kajian ini dipilih peningkatan keterampilan menulis cerpen sebagai objek penelitian. Keterampilan seorang siswa dalam hal menulis cerpen masih kurang. Sebenarnya untuk menulis cerpen lebih mudah jika dibandingkan menulis karya sastra lain seperti drama, novel ataupun puisi. Menulis cerpen tidak sesulit menulis drama yang harus menciptakan dialog antartokoh dalam cerita. Menulis cerpen tidak memerlukan waktu yang lama jika dibandingkan menulis menulis novel dikarenakan cerpen lebih pendek dibanding dengan novel. Adapun dalam menulis cerpen bahasa yang digunakan merupakan bahasa yang sederhana, lebih sederhana dibandingkan bahasa dalam puisi yaitu dengan bahasa yang singkat, bahasa cerpen mampu merangkum semua ide cerita dalam satu rangkaian tema. Dunia cerita pendek bagaikan sebuah alam di dasar laut dengan karang yang dalam. Semakin pembaca menyelam dengan minat yang tajam, makin asyik dan terpukau pembaca oleh keindahan dan kekayaannya. Untuk dapat menikmati semua itu diperlukan usaha keras dan latihan terus-menerus, sehingga akan diperoleh karya cerpen yang penuh imajinasi dan 
fantasi nyata dari kehidupan manusia. Tentunya ini akan menjadi kenangan tersendiri bagi siswa, karena telah menjadi "cerpenis" sekaligus memberi kontribusi bahan ajar dalam pembelajaran sastra di sekolah. Peran guru sebagai motivator, fasilisator sekaligus inspirator bagi siswa sangat diperlukan dalam hal ini, yakni membimbing siswa menulis kreatif cerita pendek.

Meskipun keterampilan menulis cerpen dinilai lebih mudah jika dibanding dengan keterampilan menulis karya sastra lain, kenyatannya masih banyak siswa yang kurang memiliki keterampilan tersebut. Rata-rata dari mereka kesulitan untuk menuangkan ide kreatifnya kedalam cerita. Selain itu, mereka juga mengalami kesulitan merangkai alur cerita dalam sebuah cerpen. Oleh karena itu, diperlukan usaha untuk meningkatkan keterampilan menulis cerpen, sehingga kompetensi ini dapat menunjang keterampilan siswa dalam bersastra.

Berdasarkan hasil observasi yang telah dilakukan terhadap siswa kelas X IPA 2 MA Miftahul Ulum Weding Bonang diketahui bahwa pada saat proses pembelajaran menulis kreatif cerpen siswa banyak yang mengalami kesulitan dalam menemukan ide dan menemukan pemahaman terhadap tema. Hal ini terjadi karena siswa tidak mengetahui tujuan dan manfaat dari pembelajaran menulis yang diberikan oleh pendidik. Selain tidak mengetahui tujuan dan manfaat, peserta didik juga terkendala oleh waktu. Hal tersebut karena peserta didik lebih fokus pada bagaimana cara untuk menemukan atau menyelesaikan tulisannya tanpa memperhatikan isinya.

Faktor dari guru ketika memberikan pembelajaran menulis cerpen hanya mengandalkan buku teks, tanpa menggunakan media yang lebih inovatif. Terkadang guru mengajarkan kompetensi dasar menulis hanya dengan menjawab pertanyaan-pertanyaan yang berkaitan dengan contoh cerpen yang ada serta menulis unsur-unsur intrinsik cerpen tanpa meminta siswa untuk membuat cerpen.

Penggunaan metode dan media yang diterapkan guru dalam pembelajaran menulis pun masih belum efektif, karena metode yang digunakan masih berupa metode ceramah dan media yang digunakan belum ada, sehingga apa yang diterima siswabelum maksimal dalam pembelajaran menulis. Saat proses pembelajaran berlangsung guru jarang menggunakan apersepsi untuk mengawali pembelajaran. guru langsung masuk pada materi pembelajaran, sehingga siswa sulit untuk menangkap materi yang diberikan oleh guru secara maksimal. Selain itu, pemahaman siswa terhadap materi yang diberikan oleh guru masih belum maksimal. Hal tersebut dikarenakan siswa lebih tertarik untuk mengobrol dengan teman sebangkunya dari pada memperhatikan apa yang sedang diajarkan oleh guru. Selain itu, 
kondisi ruang kelas yang sedikit panas dan keadaan di luar kelas yang sedikit ramai membuat siswa tidak fokus dalam pelajaran.

Berdasarkan hasil pengamatan yang dilakukan pada kelas X IPA 2 MA Miftahul Ulum Weding Bonang dan wawancara penulis dengan guru bahasa Indonesia, diketahui bahwa siswa lemah dalam menulis terutama dalam menulis yang ada kaitannya dengan menuangkan pikiran atau gagasan yang dimiliki peserta didik. Selain itu, masih lemah minat peserta didik dalam pembelajaran yang berhubungan dengan hal yang serius, seperti pembelajaran menulis kreatif cerpen. Lemahnya minat siswa terhadap pembelajaran menulis ini dikarenakan metode dan media yang digunakan oleh guru masih berupa metode ceramah dan tidak adanya media. Berdasarkan hasil wawancara penulis dengan guru bahasa Indonesia, keterampilan menulis kreatif cerpen peserta didik kelas X IPA 2 MA Miftahul Ulum Weding Bonang perlu ditingkatkan.

Dengan melihat kenyataan permasalahan pembelajaran menulis yang ada di sekolah, maka diperlukan penerapan teknik mengajar serta media yang lebih inovatif untuk membantu siswa dalam menulis cerpen. Dalam hal ini guru mempunyai peranan penting yang besar terhadap keberhasilan pembelajaran menulis. Guru harus menciptakan situasi belajar yang menyenangkan agar anak dapat mengembangkan kreativitasnya dalam menulis cerpen. Guru harus dapat memposisikan sebagai fasilisator dan pemicu semangat anak dalam belajar yang dapat diwujudkan dengan mencari pembelajaran yang lebih efektif. Salah satu alternatif pembelajaran yang dapat dilakukan adalah menciptakan teknik mengajar yang lebih inovatif dan media pembelajaran sehingga siswa tidak merasa bosan dan jenuh dalam mengikuti pembelajaran menulis cerpen.

Pemilihan metode yang tepat akan sangat mempengaruhi hasil belajar peserta didik. Metode mempermudah pendidik dalam pembelajaran dan model mempermudah pendidik untuk memperkuat metode yang digunakan. Dalam menentukan sebuah metode dan model seorang pendidik harus paham dengan materi yang akan diajarkan dan pendidik juga harus tahu tentang metode dan model yang akan digunakan itu sesuai atau tidak dengan materi yang akan diajarkan kepada siswa, sehingga dalam proses pembelajaran tersebut siswa dapat menagkap materi yang diajarkan dengan baik.

Salah satu metode yang tepat dalam pembelajaran keterampilan menulis yaitu Metode Show Not Tell (mengilustrasikan bukan memberitahukan). Metode ini memberikan kemudahan bagi siswa untuk melaksanakan tugas berdasarkan petunjuk guru. Selain itu, Metode Mengilustrasikan Bukan Memberitahukan dapat melatih dan membiasakan siswa untuk bermai-main secara tepat. Dengan metode ini, diharapkan siswa akan lebih mudah 
untuk menulis cerpen. Hal ini dapat mendorong siswa untuk berpikir, berinisiatif, berkreasi dan meningkatkan kreativitas sehingga dalam pembelajaran menulis cerpen siswa tidak merasa bosan dan hasil yang dicapai dapat meningkat. Selain itu, penulis juga menggunakan media film pendek sehingga dapat membantu siswa dalam berimajinasi untuk membuat sebuah cerpen yang bagus. Film pendek yang dijadikan media pembelajaran akan memberikan petunjuk serta menuntun siswa untuk menulis alur cerita dalam cerpen. Adapun Metode Mengilustrasikan Bukan Memberitahukan untuk mengubah kalimat yang dipakai siswa saat bercerita agar cerita menjadi lebih hidup.

Berdasarkan latar belakang tersebut, penggunaan metode dan media harus ditingkatkan. Oleh karena itu, penulis melakukan penelitian tindakan kelas dengan judul "Peningkatan Keterampilan Menulis Cerpen dengan Metode Mengilustrasikan Bukan Memberitahukan dan Media Film Pendek Berbasis Pendidikan Karakter padaSiswa Kelas X IPA 2 MA Miftahul Ulum Weding Bonang Kabupaten Demak”.Tujuan Penelitian ini untuk mendeskripsikan (1) pelaksanaan pembelajaran menulis cerpen dengan Metode Mengilustrasikan Bukan Memberitahukan dan media film pendek berbasis pendidikan karakter pada siswa kelas X IPA 2 MA Miftahul Ulum Weding Bonang Kabupaten Demak, (2) peningkatan keterampilan menulis cerpen dengan Metode Mengilustrasikan Bukan Memberitahukan dan media film pendek berbasis pendidikan karakterpada siswa kelas X IPA 2 MA Miftahul Ulum Weding Bonang Kabupaten Demak, dan (3) perubahan sikap dan perilaku siswa kelas X IPA 2 MA Miftahul Ulum Weding Bonang Kabupaten Demak setelah mendapat pembelajaran menulis cerpen dengan menggunakan Metode Mengilustrasikan Bukan Memberitahukan dan media film pendek berbasis pendidikan karakter.

\section{METODE PENELITIAN}

Metode penelitian yang digunakan oleh peneliti yaitu metode penelitian tindakan kelas.

\section{Desain Penelitian}

Penelitian yang digunakan oleh peneliti yaitu penelitian tindakan kelas. Menurut pengertiannya penelitian tindakan adalah penelitian tentang hal-hal yang terjadi di masyarakat atau sekelompok sasaran, dan hasilnya langsung dapat dikenakan pada masyarakat yang bersangkutan (Arikunto, 2002, hal 82). Penelitian ini merupakan penelitian yang melibatkan siswa dan guru, serta dilakukan di kelas untuk menyelesaikan permasalahan di kelas supaya pembelajaran dapat berjalan dengan lancar dan berhasil. Proses penelitian yang dilakukan oleh peneliti melalui dua siklus. Pada tahap perencanaan, peneliti menyusun 
rancangan mengajar termasuk mempersiapkan rencana pelaksanaan pembelajaran (RPP). Selanjutnya peneliti melakukan kegiatan pembelajaran dengan melaksanakan tindakan yang akan dilakukan pada penelitian. Setelah dilakukan tindakan, peneliti melakukan observasi terhadap kegiatan pembelajaran yang telah dilakukan. Kelebihan yang ada pada siklus I akan dipertahankan, sedangkan kekurangan dalam siklus I akan diperbaiki pada siklus II.

Sesuai dengan jenis penelitian yang dipilih, yaitu penelitian tindakan kelas, maka penelitian ini menggunakan model penelitian tindakan dari Kemmis dan Taggart, yaitu berbentuk spiral dari siklus yang satu ke siklus yang berikutnya. Setiap siklus meliputi planning (perencanaan), action (tindakan), observation (pengamatan), dan reflection (refleksi). Langkah pada siklus berikutnya adalah perencanaan yang sudah direvisi, tindakan, pengamatan, dan refleksi. Sebelum masuk pada siklus satu dilakukan tindakan pendahuluan yang berupa identifikasi masalah.

\section{Subjek Penelitian}

Penelitian ini merupakan penelitian tindakan kelas dengan subjek penelitian siswa kelas X IPA 2 MA Miftahul Ulum Weding Bonang yang berjumlah 36 siswa, dengan rincian 13 laki-laki dan 23 perempuan. Peneliti mengadakan penelitian di kelas X IPA 2 karena dalam kurikulum kelas $\mathrm{X}$ terdapat kompetensi dasar menulis cerpen, selain itu di kelas X IPA 2 siswa kali pertama mendapatkan materi menulis cerita pendek. Adapun karakter siswa kelas XIPA 2 MA Miftahul Ulum Weding Bonang secara keseluruhan memiliki kemampuan akademik yang seimbang atau setara antarsiswa termasuk kemampuan kognitifnya. Demikian juga dengan usia mereka secara mayoritas hampir sama atau sebaya.

\section{Variabel Penelitian}

Penelitian ini menggunakan empat variabel yaitu menulis cerpen, pembelajaran menggunakan menggunakan Metode Mengilustrasikan Bukan Memberitahukan, pembelajaran menggunakan media film pendek, dan pembelajaran dengan menggunakan basis pendidikan karakter.

\section{Instrumen Penelitian}

Instrumen penelitian yang digunakan dalam penelitian ini terdiri atas instrumen tes dan nontes.

\section{Instumen Tes}

Menurut Arikunto (2002, hal 127) tes adalah serentetan pertanyaan atau latihan atau alat lain yang digunakan untuk mengukur keterampilan, pengetahuan intelegensi, kemampuan atau bakat yang dimiliki individu atau kelompok.sedangkan menurut Brata (dalam Thoha 2003, hal 43), pengertian tes adalah pertanyaan-pertanyaan yang harus dijawab 
atau perintah-perintah yang harus dijalankan, yang mendasarkan testee menjawab pertanyaan-pertanyaan atau melakukan perintah-perintah itu, meyelidiki mengambil kesimpulan dengan cara membandingkan dengan standar atau tes lainnya.

Dari kedua pengertian diatas maka dapat diketahui bahwa tes adalah alat pengukuran berupa pertanyaan, perintah, dan petunjuk yang ditunjukan kepada testee untuk mendapatkan respon sesuai dengan petunjuk itu. Atas dasar respon tersebut ditentukan tinggi rendahnya skor dalam bentuk kuantitatif, selanjutnya dibandingkan dengan standar yang telah ditentukan untuk ditarik kesimpulan yang bersifat kuantitatif.

Instrumen tes dilakukan untuk mengetahui tingkat kemampuan siswa dalam menulis cerpen. Dalam hal ini ada beberapa aspek yang dinilai. Aspek-aspek tersebut, yaitu (1) kesesuaian tema cerpen dengan media teks dari film pendek, (2) keruntunan alur cerita, (3) penggambaran tokoh dan penokohan, (4) pendeskripsian latar, dan (5) penggunaan gaya bahasa. Dalam penilaian tiap aspek ditentukan skor maksimum dan tiap aspek memiliki skor maksimum yang berbeda-beda sesuai dengan tingkat kesulitannya.

\section{Instrumen Nontes}

Instrumen nontes digunakan untuk mengetahui sikap siswa ketika mengalami pembelajaran menulis cerpen dengan Metode Mengilustrasikan Bukan Memberitahukan dan media film pendek. Bentuk instrumen yang digunakan dalam penelitian ini adalah pedoman observasi, jurnal, wawancara, angket atau kuesioner, dan dokumentasi.

\section{Teknik Pengumpulan Data}

Teknik pengumpulan data yang digunakan dalam penelitian ini adalah teknik tes dan nontes. Teknik pengumpulan data tes digunakan untuk mengetahui kemampuan siswa dalam menulis cerpen setelah dilakukan pembelajaran dengan Metode Mengilustrasikan Bukan Memberitahukan dan media film pendek. Teknik nontes digunakan untuk mengetahui respon siswa terhadap pembelajaran menulis cerpen dengan Metode Mengilustrasikan Bukan Memberitahukan dan media film pendek.

\section{Teknik Tes}

Data dalam penelitian ini diperoleh dengan menggunakan tes yang dilakukan sebanyak tiga kali. Tes ini dijadikan sebagai tolak ukur peningkatan keberhasilan siswa dalam menulis cerpen setelah menggunakan metode dan media dalam tindakan yang dilakukan. Tes menulis cerpen ini berupa lembar tugas berisi perintah kepada siswa untuk menulis cerpen. Hasil tes berupa cerpen.

\section{Teknik Nontes}


Teknik nontes yang digunakan dalam penelitian ini adalah observasi, wawancara, jurnal, angket, dan dokumentasi foto.

\section{Teknik Analisis Data}

Teknik analisis data pada penelitian ini dilakukan secara kuantitatif dan kualitatif.

\section{Teknik Kuantitatif}

Teknik kuantitatif digunakan untuk menganalisis data kuantitatif. Data ini diperolehdengan cara menganalisis nilai secara keseluruhandan merekap nilai tes menulis cerpen dengan Metode Mengilustrasikan Bukan Memberitahukan dan media film pendek dari siklus I, siklus II, dan siklus III. Nilai masing-masing siklus dihitung jumlahnya kemudian dihitung dalam persentase dengan rumusan sebagai berikut (Widoyoko, 2013, hal 37).

$$
N P=\frac{R}{J S} \times 100 \%
$$

\section{Keterangan}

$\mathrm{NP} \quad=$ nilai dalam persen

$\mathrm{R} \quad \quad=$ skor yang dicapai siswa

JS $\quad=$ jumlah seluruh siswa

Hasil penghitungan siklus I, siklus II, dan siklus III dibandingkan akan memberikan gambaran persentase peningkatan keterampilan menulis cerpen dengan Metode Mengilustrasikan Bukan Memberitahukan dan media film pendek. Dengan adanya peningkatan berarti pembelajaran menulis cerpen berhasil.

\section{Teknik Kualitatif}

Teknik kualitatif dipakai untuk menganalisis data kualitatif. Data kualitatif diperoleh dari hasil nontes, yaitu observasi, wawancara, jurnal, angket, dan dokumentasi foto. Hasil analisis data observasi akan memberi gambaran siswa yang mandapat nilai kurang apakah dia akan tetap berperilaku negatif atau sebaliknya apakah siswa yang mendapat nilai tertinggi akan selalu berperilaku positif. Data dari wawancara, jurnal, dan dokumentasi foto dapat diketahui kesulitan apa saja yang dialami siswa dalam pembelajaran. Jurnal siswa dan wawancara pada dasarnya sama, tetapi jurnal siswa merupakan jawaban tertulis dari seluruh siswa, sedangkan wawancara adalah jawaban lisan dari tiga orang siswa. Kedua instrumen tersebut dipakai untuk mencari kesesuaian antara pendapat yang didapat dari jurnal siswa dan dari hasil wawancara. Oleh karena itu, lembar jurnal siswa danwawancara digunakan untuk teknik pengambilan data.

Penelitian tindakan kelas ini akan lebih memberikan gambaran secara nyata mengenai kegiatan pembelajaran dan minat masing-masing siswa apabila disertai 
dokumentasi foto. Dokumentasi foto berupa pendeskripsian fenomena-fenomena yang muncul dalam foto selama proses pembelajaran berlangsung merupakan bukti autentik dari aktivitas siswa.

\section{HASIL PENELITIAN DAN PEMBAHASAN}

Penelitian-penelitian yang berkaitan dengan penelitian menulis cerpen ini antara lain Rahayu (2007), Septiani (2007), Gunersel (2009), Sulistyo (2009), Saputri (2009), Pressanti (2009), Pusparingga (2010), Fitryana (2011), Ghasemi (2011), Maghfiroh (2011), Nurhayati (2011), Chiramance (2014), Juniastuti, et al (2014), Manik (2014), Manik (2015), dan Merindriasari, et al (2015). Berikut merupakan hasil penelitian ini yang dilakukan selama tiga siklus yaitu siklus I, siklus II, dan siklus III. Pembahasan hasil tersebut meliputi hasil penelitian tes dan nontes. Pembahasan hasil tes mengacu pada perolehan nilai yang dicapai oleh siswa dalam menulis cerpen dengan Metode Show Not Tell dan media film pendek berbasis pendidikan karakter. Hasil dari siklus I, siklus II, dan siklus III tersebut akan memberikan dampak pada pelaksanaan pembelajaran menulis cerpen dengan Metode Show Not Tell dan media film pendek berbasis pendidikan karakter pada siswa kelas X IPA 2 MA Miftahul Ulum Weding Bonang Demak. Siswa kelas X IPA 2 MA Miftahul Ulum Weding Bonang Demak telah mendapatkan pengajaran menulis cerpen dengan Metode Show Not Tell dan media film pendek. Berikut pembahasan hasil penelitian pada siklus I, siklus II, dan siklus III.

\section{Pelaksanaan Pembelajaran Menulis Cerpen dengan Metode Show Not Telldan Media Film Pendek Berbasis Pendidikan Karakter pada Siswa Kelas X IPA 2 MA Miftahul Ulum Weding Bonang Demak}

Pelaksanaan pembelajaran menulis cerpen dengan Metode Show Not Telldan media film pendek berbasis pendidikan karakter dimulai dengan perkenalan dengan peserta didik kemudian dilanjutkan pada proses pembelajaran siklus I. Kegiatan pembelajaransiklus I diawali dengan guru memberikan apersepsi pembelajaran menulis cerpen. Melalui kegiatan ini siswa menjadi tahu apa manfaat dan tujuan yang hendak dicapai dalam pembelajaran menulis cerpen. Kegiatan inti diawali dengan guru memberikan materi unsur-unsur pembangun cerpen. kemudian guru memberikan penjelasan tentang Metode Show Not Telldan menayangkan media film pendek yang akan digunakan untuk menulis cerpen. Selanjutnya siswa diberikan waktu untuk menulis cerpen berdasarkan film pendek yang telah 
ditayangkan. Setelah itu siswa diminta membacakan cerpen yang dibuat dan siswa lain mengomentari. Kegiatan penutup pada siklus I adalah pembahasan dan refleksi bersama.

Rangkaian pada siklus I juga diterapkan pada pembelajaran siklus II dan siklus III. Yang membedakan adalah pemberian motivasi kepada siswa berupa pemberian reward kepada siswa. Hal ini dilakukan agar siswa termotivasi untuk menulis cerpen dengan lebih baik.Pola pembelajaran yang sama pada siklus I, siklus II, dan siklus III tidak membuat siswa bosan, karena guru menggunakan film pendek yang berbeda.

\section{Peningkatan Keterampilan Menulis Cerpen dengan Metode Show Not Tell dan Media} Film Pendek Berbasis Pendidikan Karakter pada Siswa Kelas X IPA 2 MA Miftahul Ulum Weding Bonang Demak

Sebelum peneliti melakukan penelitian pada kelas X IPA 2 MA Miftahul Ulum, peneliti terlebih dahulu melakukan observasi awal dan wawancara terhadap guru mata pelajaran Bahasa Indonesia kelas X IPA 2. Hal ini dilakukan dengan tujuan untuk mengetahui gambaran kondisi awal siswa tentang keterampilan menulis, khususnya menbulis cerpen. Setelah dianalisis, peneliti kemudian melakukan penelitian yang dilakukan dalam tiga siklus yaitu siklus I, siklus II, dan siklus III. Siklus II dan siklus III dilaksanakan apabila pada siklus I terdapat beberapa kekurangan yang dapat diketahui dari hasil tes dan nontes pada siklus I. Dari kegiatan tes dan nontes tersebut kemudian dapat disimpulkan kegiatan apa saja yang harus dilakukan untuk memperbaiki pembelajaranpada siklus selanjutnya. Peneliti menggunakan Metode Show Not Telldan media film pendek untuk meningkatkan keterampilan menulis cerpen siswa kelas X IPA 2 MA Miftahul Ulum Demak. Hasil tes menulis cerpen pada siklus I, siklus II, dan siklus III dapat dilihat pada Tabel 1 berikut.

Tabel 1 Hasil Tes Keterampilan Menulis Cerpen Siklus I, Siklus II, dan Siklus III

\begin{tabular}{|c|c|c|c|c|c|c|c|}
\hline \multirow{2}{*}{ No. } & \multirow{2}{*}{ Aspek Penilaian } & \multicolumn{3}{|c|}{ Nilai Rata-Rata Kelas } & \multicolumn{3}{|c|}{ Peningkatan } \\
\hline & & S I & S II & S III & S I-S II & S II-S III & S I-S III \\
\hline 1 & $\begin{array}{l}\text { Kesesuaian tema } \\
\text { cerita }\end{array}$ & 66,11 & 71,44 & 76,25 & 5,33 & 4,81 & 10,14 \\
\hline 2 & $\begin{array}{l}\text { Penggunaan alur atau } \\
\text { plot }\end{array}$ & 65,11 & 72,83 & 77,58 & 7,72 & 4,75 & 12,47 \\
\hline 3 & $\begin{array}{l}\text { Penggambaran tokoh } \\
\text { dan penokohan }\end{array}$ & 67,69 & 72,02 & 76,19 & 4,33 & 4,17 & 8,50 \\
\hline 4 & Pendeskripsian latar & 69,22 & 72,25 & 75,63 & 3,03 & 3,38 & 6,41 \\
\hline 5 & $\begin{array}{l}\text { Penggunaan gaya } \\
\text { bahasa }\end{array}$ & 66,00 & 69,00 & 72,86 & 3,00 & 3,86 & 6,86 \\
\hline & ata-Rata Nilai Kelas & 66,83 & 71,50 & 75,70 & 5,67 & 4,20 & 8,87 \\
\hline
\end{tabular}


Berdasarkan hasil tes keterampilan menulis cerpen siklus I, siklus II, dan siklus III dapat dijelaskan bahwa keterampilan menulis cerpen pada tiap aspek mengalami peningkatan. Rata-rata nilai pada aspek kesesuaian tema cerita pada siklus I sebesar 66,11. Pada siklus II nilai rata-rata sebesar 71,44 atau meningkat sebesar 5,33. Pada siklus III nilai rata-rata sebesar 76,25 ataumeningkat sebesar 4,81. Peningkatan siklus I sampai siklus III sebesar 10,14.Aspek penggunaan alur atau plot pada siklus I sebesar 65,11.Pada siklus II nilai rata-rata sebesar 72,83 atau meningkat sebesar 7,72. Pada siklus III sebesar 77,58 atau meningkat sebesar 4,74. Peningkatan siklus I sampai siklus III sebesar 12,47. Aspek penggambaran tokoh dan penokohan pada siklus I nilai rata-rata sebesar 67,69.Pada siklus II nilai rata-rata sebesar 72,02 atau meningkat sebesar 4,33. Pada siklus III sebesar 76,19 atau meningkat sebesar 4,17. Peningkatan siklus I sampai siklus III sebesar 8,50. Untuk aspek pendeskripsian latar pada siklus I nilai rata-rata sebesar 69,22. Pada siklus II nilai rata-rata sebesar 72,25 atau meningkat sebesar 3,03. Pada siklus III sebesar 75,63 atau meningkat sebesar 3,38. Peningkatan siklus I sampai siklus III sebesar 6,41. Adapun aspek penilaian terakhir yaitu aspek penggunaan gaya bahasa pada siklus I nilai rata-rata sebesar 66,00. Pada siklus II nilai rata-rata sebesar 69,00 atau meningkat sebesar 3,00. Pada siklus III sebesar 72,86 atau meningkat sebesar 6,86. Peningkatan siklus I sampai siklus III sebesar 6,86. Ratarata nilai kelas pada siklus I sebesar 66,83, Pada siklus II sebesar 71,50 atau meningkat sebesar 5,67. Sedangkan pada siklus III sebesar 75,70 atau meningkat sebesar 4,20. Peningkatan siklus I sampai siklus III sebesar 8,87.

\section{Perubahan Perilaku Siswa Kelas X IPA 2 MA Miftahul Ulum Weding Bonang Demak Setelah Mendapatkan Pengajaran Menulis Cerpen dengan Metode Show Not Tell dan Media Film Pendek Berbasis Pendidikan Karakter}

Berdasarkan hasil nontes yang berupa observasi, jurnal siswa, jurnal guru, angket atau kuesioner, dan dokumentasi foto dapat diketahui bahwa ada sebagian siswa yang belum siap dalam mengikuti pembelajaran menulis cerpen melalui Metode Show No Tell dan media film pendek. Dari hasil observasi siklus I diketahui bahwa kesiapan siswa dalam mengikuti pembelajaran menulis cerpen masih belum memuaskan. Sebagian dari mereka masih menunjukkan perilaku yang negatif ketika menerima pembelajaran dan kurang konsentrasi menerima materi yang disampaikan guru. Hal ini tampak dengan adanya siswa yang masih senang berbicara dengan teman sebelahnya, ada yang melamun, atau bahkan mengantuk dan melakukan hal yang tidak penting seperti bermain-main alat tulis serta mengganggu teman 
sebangkunya, juga ada yang kurang bersemangat dalam mengikuti pembelajaran menulis cerpen.

Hambatan yang ada dalam siklus I yaitu siswa masih mengandalkan pekerjaan teman dan tidak mengerjakan pekerjaannya secara mandiri. Selain itu, penguasaan kosa kata siswa juga kurang sehingga memengaruhi gaya bahasa dalam penulisan cerpen.

Permasalahan yang terjadi pada siklus I dipecahkan untuk upaya perbaikan pada pembelajaran menulis cerpen siklus II. Perbaikan yang dilakukan pada siklus II yaitu guru lebih memotivasi siswa dalam pembelajaran menulis cerpen, membuat suasana lebih santai agar dapat mengurangi ketegangan. Guru juga memberikan reward kepada siswa yang mampu menulis cerpen dengan baik supaya siswa lebih tertarik untuk mengikuti proses pembelajaran. Guru menjelaskan kesalahan-kesalahan yang dilakukan siswa pada siklus I supaya siswa tidak mengulanginya lagi. Perubahan ini ternyata dapat meningkatkan kemampuan siswa dalam menulis cerpen.

Hasil dari penerapan perbaikan-perbaikan yang dilakukan pada siklus II ini ternyata berdampak positif dan cukup memuaskan. Berdasarkan hasil observasi pada siklus III siswa tampak lebih siap dalam mengikuti pembelajaran. Siswa bersungguh-sungguh mengikuti pembelajaran menulis cerpen, mereka lebih percaya diri dan tidak tampak malu-malu untuk bertanya ketiak mengalami kesulitan. Sikap siswa juga cenderung lebih menuju ke arah yang positif.

Dari hasil jurnal siswa pada siklus I, siklus II, dan siklus III dapat disimpulkan bahwa terjadi perubahan perilaku ke arah yang lebih baik. Pada siklus I siswa masih kurang mamahami materi yang disampaikan guru, pada siklus II siswa sudah memahami penjelasan dari guru. Adapun pada siklus III siswa sudah lebih memahami penjelasan dari guru dan siswa dapat menerapkan MetodeShow Not Tellsaat menulis cerpen. Pemberian motivasi dan penghargaan kepada siswa menjadikan siswa bersemangat, senang, dan ada ketertarikan dalam mengikuti pembelajaran menulis cerpen.

Dari hasil wawancara pada ketiga siswa yang memperoleh nilai tinggi, sedang, dan rendah diperoleh keterangan bahwa dengan adanya Metode Show Not Tell membantu mereka dalam menemukan ide, alur, dan kata-kata untuk menulis cerpen. Pada siklus I siswa belum maksimal memahami penjelasan dari guru, pada siklus II siswa mulai memahami penjelasan dari guru, namun pada siklus IIIsiswa lebih serius dan memahami penjelasan dari guru sehingga ketika menerapkan Metode Show Not Tell tidak mengalami kesulitan.

Dari hasil dokumentasi yang sudah diambil oleh peneliti, terjadi perubahan positif dari siklus I, siklus II, ke siklus III. Pada siklus I siswa masih kurang serius ketika 
mendengarkan penjelasan dari guru. Pada siklus II siswa serius ketika mendengarkan penjelasan dari guru. Adapun pada siklus III siswa sudah lebih serius mendengarkan penjelasan dari guru. Tidak ada siswa yang bermalas-malasan dan kurang semangat mengikuti pembelajaran. Mereka serius dan bersungguh-sungguh dalam mengikuti pembelajaran menulis cerpen.

Perubahan tingkah laku belajar siswa pada siklus III dari hasil observasi, jurnal siswa dan guru, wawancara, angket atau kuesioner, dan dokumentasi dapat disimpulkan bahwa terjadi perubahan perilaku siswa ke arah yang lebih baik pada siklus III. Kondisi awal menunjukkan sebagian siswa berperilaku negatif dan kurang bersemangat dalam mengikuti pembelajaran. Tindakan yang dilakukan peneliti yaitu memberi motivasi kepada siswa agar lebih bersemangat dalam mengikuti pembelajaran berikutnya. Terbukti setelah guru memberikan motivasi, siswa menjadi lebih bersemangat dan tertarik untuk menulis cerpen. Pada siklus III sudah tidak lagi terlihat sikap negatif siswa yang mencolok ketika pembelajaran sedang berlangsung.

Berdasarkan hasil analisis data dan situasi pembelajaran pada siklus I, siklus II, dan siklus III dapat dijelaskan adanya peningkatan yang lebih baik. Pada siklus I keterampilan siswa menulis cerpen masih kurang sedangkan siklus II mengalami peningkatan, dan lebih meningkat lagi pada siklus III. Siswa sudah mampu menulis cerpen dengan baik. Peningkatan nilai tes siswa juga diikuti dengan perubahan perilaku siswa yang semakin baik. Pada siklus I siswa masih kurang bersemangat mengikuti pembelajaran, siswa masih kurang memerhatikan penjelasan dari guru, dan mengalami kesulitan ketika menentukan alur cerita dari cerpen yang akan dibuat. Namun pada siklus II dan siklus III siswa semakin bersemangat untuk menulis cerpen, serius memerhatikan penjelasan dan bimbingan dari guru serta bersungguhsungguh mengikuti pembelajaran menulis cerpen sehingga mereka tidak mengalami kesulitan dalam menulis cerpen. Oleh karena itu, dapat disimpulkan bahwa melalui MetodeShow Not Tell dan media film pendek mampu meningkatkan keterampilan menulis cerpen siswa kelas X IPA 2 MA Miftahul Ulum Weding Bonang Demak. Selain itu, melalui metode dan media ini pembelajaran menulis cerpen menjadi lebih menyenangkan bagi siswa, karena siswa tidak merasa kebingungan saat menentukan tema, menggambarkan tokoh, menggunakan alur cerita, menggunakan gaya bahasa, dan cara mendeskripsikan latar cerita. Oleh karena itu, Metode Show Not Tell dan media film pendek dapat digunakan dalam pembelajaran menulis cerpen. 


\section{PENUTUP}

Berdasarkan hasil penelitian dan pembahasan pada keterampilan menulis cerpen dengan Metode Mengilustrasikan Bukan Memberitahukan dan media film pendek berbasis pendidikan karakter dapat disimpulkan sebagai berikut.

1. Keterampilan menulis cerpen siswa kelas X IPA 2 MA Miftahul Ulum Weding mengalami peningkatan setelah mengikuti pembelajaran menulis cerpen melalui Metode Mengilustrasikan Bukan Memberitahukan dan media film pendek. Pada siklus I, nilai rata-rata kelas X IPA 2 IPA 2 MA Miftahul Ulum mencapai 66,83 dan termasuk kategori kurang. Pada siklus II, nilai rata-rata kelas mengalami peningkatan sebesar 5,67\% menjadi 71,50 dan termasuk kategori cukup baik. Kemudian pada siklus III, nilai ratarata kelas mengalami peningkatan sebesar 4,20\% menjadi 75,70 dan termasuk kategori baik. Perolehan hasil ini menunjukkan bahwa pembelajaran menulis cerpen siswa kelas X IPA 2 MA Miftahul Ulum melalui Metode Mengilustrasikan Bukan Memberitahukan dan media film pendek dapat dikatakan berhasil.

2. Perilaku siswa kelas X IPA 2 MA Miftahul Ulum dalam mengikuti pembelajaran menulis cerpen melalui Metode Mengilustrasikan Bukan Memberitahukan dan media film pendek mengalami perubahan ke arah positif. Perubahan tersebut terlihat dari data nontes yaitu observasi, wawancara, jurnal guru dan siswa, angket atau kuesioner, dan dokumentasi foto. Hasil data nontes tersebut menunjukkan siswa terlihat lebih antusias dan senang saat pembelajaran menulis cerpen melalui Metode Mengilustrasikan Bukan Memberitahukan Mengilustrasikan Bukan Memberitahukan dan media film pendek.

\section{DAFTAR PUSTAKA}

Chiramance, Thanyapa. (2014). Journal Writing with Peer Feedback: A Friend or A Foe for EFL Learners. International Journal of English Languange Education, 2 (2).

Depdiknas. (2003). Standar Kompetensi Mata pelajaran Bahasa dan Sastra Indonesia. Jakarta: Depdiknas.

Depdiknas. (2004). Standar Isi Kurikulum KTSP. Jakarta: Pusat Kurikulum.

Fitryana, Dewi Ika. (2011). Peningkatan Keterampilan Menulis Cerpen Melalui Media Berita dengan Media Latihan Terbimbing pada Siswa Kelas X.3 SMA Negeri 1 Rembang Purbalingga. Skripsi. Yogyakarta: Fakultas Bahasa dan Seni UNY.

Ghasemi, Parvin. (2011). Theaching the Short Story to Improve L2 Reading and Writing Approaches and Strategis. International Journal of Art and Sciences, 4 (18). 
Gunersel, (2009). Improvement in Writing and Reviewing Skills with Calibrated Peer Review. International Journal for the Scholarship of Teaching and Learning, 3 (2).

Juniastuti, Ni Putu Esti, et.al. (2014). Penerapan Teknik Parafrasa terhadap Naskah Drama untuk Meningkatkan Kemampuan Menulis Cerpen Siswa Kelas IX D SMP Negeri 5 Amlapura. Jurnal Jurusan Pendidikan dan Sastra Indonesia, 2 (1).

Laksana. (2009). Keterampilan Menulis Kreatif. Yogyakarta: Kanisius.

Maghfiroh, Laeli. (2010). Pemanfaatan Show Not Tell untuk Meningkatkan Keterampilan Menulis Karangan Deskripsi pada Siswa Kelas IV di SD Negeri 3 Tunjungmuli Kabupaten Purbalingga. Tesis. Semarang: Unnes.

Manik, Maria Krisnauli. (2014). Pengaruh Teknik Menunjukkan Bukan Memberitahu (Show Not Tell) terhadap Kemampuan Menulis Puisi oleh Siswa Kelas X SMA Swasta Budisatrya Medan Tahun Pembelajaran 2013/2014. Skripsi. Medan: Universitas Negeri Medan.

Manik, Sondang, et al. (2015). Improve Student's Narrative Writing Achievement through Film at SMA Negeri 1 Palipi. International Journal of English Linguistics, 5 (2).

Merindriasari, Kiki, et al. (2015). The Use of Animated Short Film as Media for Teaching English Narrative Writing. Jurnal Pembelajaran dan Pendidikan, 4 (2).

Nurhayati. (2011). Meningkatkan Keterampilan Menulis Cerita Pendek dengan Bermain Imajinasi dan Mind Map pada siswa kelas X SMA Smart Ekselensia Indonesia.” Jurnal Nasional, 2 (5).

Pusparingga, Yeni. (2010). Peningkatan Keterampilan Menulis Cerpen Melalui Teknik Pengandaian Diri Sebagai Tokoh Drama Siswa SMA Negeri 1 Boja. Skripsi. Semarang: Universitas Negeri Semarang.

Pressanti, Dessi. (2005). Gaya Bercerita Remaja dalam Antologi Cerpen Remaja Menggapai Langit. Jurnal Alayasastra, 5 (1). Semarang: Balai Bahasa.

Rahayu, Kiki. (2007). Peningkatan Menulis Cerpen dengan Teknik Latihan Terbimbing Berdasarkan Ilustrasi Tokoh Idola Siswa Kelas X.4 SMA Negeri 1 Wanadadi Banjarnegara. Skripsi. Semarang: Universitas Negeri Semarang.

Saputri, Purwadyani. (2009). Peningkatan Keterampilan Menulis Cerpen Menggunakan Teknik Membuat Kerangka Tulisan dengan Media Lirik Lagu Kelas X.B SMA N 1 Godong Tahun 2008/2009. Skripsi. Semarang: Universitas Negeri Semarang.

Septiani, Nurul Melti Indah. (2007). Peningkatan Keterampilan Menulis Cerpen melalui Teknik Pengandaian Diri sebagai Cerita dengan Media Audio Visual pada Siswa Kelas X.4 SMA Negeri 1 Tegal. Skripsi. Semarang: Universitas Negeri Semarang. 
Subyantoro. 2009. Penelitian Tindakan Kelas. Semarang: Badan Penerbit Universitas Diponegoro.

Sugiyono, 2008. Metode Penelitian Kuantitatif Kualitatif dan R\&D. Bandung: Alfabeta.

Suharianto, S. 2009. Dasar-Dasar Teori Sastra. Surakarta: Widya Duta.

Sulistyo, Budi. 2009. Penerapan Teknik Show Not Tell dalam Pembelajaran Mengubah Teks Wawancara menjadi Teks Narasi bagi Pembentukan Karakter Siswa Kelas VII SMP Negeri 22 Semarang. Skripsi. Semarang: Universitas Negeri Semarang.

Thoha, M. Chabib. 2003. Tenik Evaluasi Pendidikan. Jakarta: PT Rosda Karya. 